\title{
EPIDEMIOLOGY OF PARACOCCIDIOIDOMYCOSIS
}

\author{
Roberto MARTINEZ
}

\begin{abstract}
SUMMARY
The epidemiological characteristics of paracoccidioidomycosis were reviewed and updated. The new endemic areas in Brazil were discussed in the section regarding the geographic distribution of the mycosis. Subclinical infection with Paracoccidioides brasiliensis was discussed on the basis of skin test surveys with antigens of the fungus, seroepidemiological studies, and disease cases outside Latin America. Large case series permitted a comparison of the prevalence of the mycosis in different regions, its estimated incidence and risk factors for the development of the disease. Aspects modulating the expression of the clinical forms of paracoccidioidomycosis are also presented. This review also deals with diseases associated with the mycosis, opportunistic paracoccidioidomycosis, lethality, mortality and infection and disease in animals.
\end{abstract}

KEYWORDS: Paracoccidioidomycosis; P. brasiliensis; Epidemiology.

\section{INTRODUCTION}

Paracoccidioidomycosis is an endemic fungal disease acquired exclusively in Latin American countries, and that presents a greater prevalence in South America. Its etiological agent is the dimorphic fungus Paracoccidioides brasiliensis, which causes an infection that may progress to systemic granulomatous disease with tegumentary and visceral disease. $P$. lutzii is another species recently identified within the genus Paracoccidioides, whose endemic area involves the Midwest and North regions of Brazil ${ }^{58}$. The characteristics of the disease caused by $P$. lutzii are still poorly known and therefore its epidemiology will not be considered in the present review.

Natural infection with P. brasiliensis occurs in men and animals and is acquired by the respiratory route after inhalation of fungal conidia suspended in air. Epidemiological surveys have permitted to estimate that many people have been infected with $P$. brasiliensis without developing the mycosis. This condition is known as paracoccidioidomycosisinfection, in which the presence of the latent fungus in residual lung lesions and mediastinal lymph nodes is possible. Transmission of the disease through the skin or the mucosa is unlikely due to the low number of fungal propagules inoculated subcutaneously in small traumas. A case of accidental percutaneous inoculation in the laboratory only caused a local granulomatous reaction ${ }^{18}$. There is no evidence of human transmission of paracoccidioidomycosis.

Paracoccidioidomycosis disease manifests as two main clinical forms that are epidemiologically distinct.
The acute/subacute form commonly affects children and young adults who tend to show more disseminated lesions. This form of the mycosis is assumed to appear a few weeks or months after infection with $P$. brasiliensis and therefore such cases, especially those involving children, are indicators of endemic areas of paracoccidioidomycosis ${ }^{77}$. The chronic form of the disease is more common among adult men who present lesions usually involving the oral mucosa, the airways and the lungs. This form of the disease manifests months to years after $P$. brasiliensis infection and has been associated with specific risk factors.

Paracoccidioidomycosis has a great medical and social impact in the areas of higher endemicity, not only because of the considerable number of cases, but also because of the chronicity of the disease, the long duration of treatment and the frequent sequelae that cause inability to work and poor quality of life. Among the causes of chronic granulomatous infectious diseases in Brazil, paracoccidioidomycosis is less frequent than tuberculosis, but is more common than histoplasmosis. Conversely, opportunistic histoplasmosis occurring in AIDS and other types of immunosuppression is more frequent than paracoccidioidomycosis.

The approach to the epidemiology of $P$. brasiliensis disease meets some difficulties due to the fact that case notification is not obligatory and to the difficulty in recognizing recently acquired infection, the absence of epidemic outbreaks, and also the deficient laboratory diagnostic capacity in some endemic areas. The epidemiology of paracoccidioidomycosis should be complemented with the ecology of the mycosis, which is reviewed in the same issue of this journal. 


\section{Geographic distribution}

Delimitation of the endemic area: Autochthonous cases of paracoccidioidomycosis are limited to the American continent, approximately between $23^{\circ} \mathrm{N}$ and $35^{\circ} \mathrm{S}$, i.e., from Mexico to Argentina ${ }^{77}$. The distribution of cases of paracoccidioidomycosis and the rates of infection with $P$. brasiliensis in population samples are heterogeneous in different countries and in different regions of each country and reveal the areas with higher endemicity. About $80 \%$ of the cases reported occurred in Brazil, and most of the remaining ones occurred in Venezuela, Colombia and Argentina. Autochthonous human paracoccidioidomycosis has not been reported in some countries such as Chile, Guyana, Surinam, French Guyana, Belize and Nicaragua. A large endemic area exists in Brazil, comprising the Southeast (States of Sao Paulo, Rio de Janeiro, Espirito Santo and Minas Gerais), Midwest (mainly the States of Goias and Mato Grosso do Sul) and South (from Parana to the North of Rio Grande do Sul). A second endemic area is located along the Eastern border of the Amazon region, including the States of Para, Maranhao and Tocantins ${ }^{28}$. A third area that became relevant at the beginning of the $21^{\text {st }}$ century comprises the Western Amazon region and the State of Rondonia in particular $^{96}$. In contrast, a large part of the Brazilian Northeast has low endemicity of paracoccidioidomycosis and no autochthonous cases appear to exist in this semi-arid region.

The endemic area of Mexico is located in the South between the Gulf of Mexico and the Pacific Coast ${ }^{51}$. In this region, as well as in all of Central America, the endemicity of the mycosis is low. The endemic area of Venezuela is mainly located in the North and in the State of Bolivar $^{60}$, while in Colombia paracoccidioidomycosis is more prevalent in the Andean region ${ }^{89}$. Endemicity is also recognized in the Rio Cuenca Valley in Ecuador ${ }^{49}$, in the region of the Peruvian Amazon forest ${ }^{13}$, in the Northeast and Northwest of Argentina ${ }^{94}$, in the Eastern half of Paraguay $^{81}$, and in most of the Bolivian territory with tropical climate ${ }^{95}$. The endemicity of paracoccidioidomycosis is low in other regions of South America such as Uruguay ${ }^{23}$, and the epidemiological situation is unknown in extensive territories of various countries.

Social and environmental changes with an epidemiological impact: The number of cases of paracoccidioidomycosis is small among Brazilian indigenous populations whose subsistence is based on hunting and fishing ${ }^{38}$ and also in a case series of the Amazon region between 1973 and $1983^{88}$, where there was a higher prevalence of lobomycosis. The first known change in the epidemiology of the mycosis possibly occurred in the Brazilian Southeast in the first half of the $20^{\text {th }}$ century, when agricultural activity has strongly expanded, particularly regarding coffee culture. Japanese and European immigrants were recruited to work on coffee plantations or in other activities linked to the soil. Many of these immigrants acquired paracoccidioidomycosis, so that $38 \%$ of the 750 cases diagnosed in the city of Sao Paulo up to 1945 involved immigrants from Japan, Portugal, Spain and Italy ${ }^{2}$. The agricultural expansion that occurred in the states of Maranhao and Para during the second half of the $20^{\text {th }}$ century was probably causally related to the endemic area located in the Eastern border of the Amazon region ${ }^{28}$. Since 1997 there is a great elevation in the number of paracoccidioidomycosis cases in Rondonia, particularly in the Southeast region of this state located in Western Amazon. This new hyperendemic area developed recently, a fact attributed to deforestation and to the wide expansion of agriculture and cattle breeding, in addition to the arrival of many immigrants from various states ${ }^{96}$. In the same region, cases of the mycosis occurred among Indians of the Surui tribe, who changed their subsistence habits and started to work on coffee culture. Skin tests demonstrated that $P$. brasiliensis infection was more common in this tribe than in neighboring tribes not involved with agricultural activity ${ }^{22}$.

Environmental and climate changes may cause alteration of the epidemiology of the mycosis. The construction of the Yacyreta dam in the Northeast of Argentina altered the valley of the Parana River and had an impact on the rates of paracoccidioidomycosis-infection among the inhabitants of the region, where cases of the mycosis were previously $\operatorname{rare}^{56}$. A similar modification may have occurred in the South of Brazil in the micro-region of the Itaipu dam, where 102 cases of paracoccidioidomycosis were recorded during a period of 18 months from 2008 to $2009^{52}$.

Climate changes, particularly the increased air and soil humidity in previous years, were associated with an increased incidence of cases of the acute/subacute form of the mycosis ${ }^{6}$. In contrast, a progressive reduction of number of cases of acute/subacute form of paracoccidioidomycosis was observed in the Mato Grosso do Sul State, which may have been a consequence of the public control policy and reduction of child labor ${ }^{33}$. Other epidemiological changes can be expected due to the growing urbanization of the population and the changes in agricultural practices, such as mechanization of farm work and the replacement of coffee with sugar cane plantations in the Brazilian Southeast.

Paracoccidioidomycosis in non-endemic countries: At least 60 cases of paracoccidioidomycosis have been reported and diagnosed in countries outside Latin America. The cases were observed in the United States of America, Canada, Spain and other European countries, the Middle East, Japan and Africa. The first 42 cases were reviewed in $1985^{1}$ and other 21 cases diagnosed in Spain since 1962 were reviewed in 2012 12 . In Japan, imported paracoccidioidomycosis was identified in at least 17 patients and a tendency to an increase in the annual number of cases was observed $^{45}$. The most recent cases were observed in Germany ${ }^{86}$, England ${ }^{97}$, Spain $^{67}$, France ${ }^{47}$, the Netherlands ${ }^{92}$ and Japan ${ }^{70}$. Each patient had been previously visiting one or more South American countries, including Brazil, Venezuela, Bolivia, Ecuador, Argentina and Paraguay.

All 60 cases were considered to be imported paracoccidioidomycosis since the patients had reported visiting or working in South or Central American countries. Some of them had left the endemic area already presenting clinical manifestations of the mycosis, but most of them had shown lesions after at least five years of permanence in non-endemic countries. These cases are indicators of endemic sites of the mycosis.

\section{Paracoccidioidomycosis-infection}

Surveys with skin reactions: The skin test with the intradermal application of $P$. brasiliensis antigens is used to assess delayed hypersensitivity and is the method most frequently used to detect asymptomatic infection with the fungus. Many epidemiological surveys for the assessment of paracoccidioidomycosis-infection have been conducted on samples of the general population or on children and other selected groups in Latin American countries. Studies on large numbers of individuals were started in 1951 and the results of many of them were included in two reviews published in $1988^{73}$ and $1998^{35}$. Table 1 shows a 
similar mean reactivity of 25 to $35 \%$ observed in four of five Brazilian regions. The lowest rate was observed in the North region $(16 \%)$. The mean percentage for the Northeast $(30.6 \%)$ is relatively high and is in contrast to the small number of cases of the mycosis in most of the States in this region. Despite the wide variability in the percentage of reactivity detected in each study, even in areas close to one another, the results suggest that infection with $P$. brasiliensis can be acquired in a large extension of the Brazilian territory. Studies conducted in other South American countries have shown higher population reactivity in Venezuela, Colombia and Ecuador. A single study carried out in Chile did not detect individuals reacting to $P$. brasiliensis (Table 1).

In general, studies with the skin test show that men and women are equally infected with $P$. brasiliensis and that infection already occurs during the first and second decades of life $\mathrm{e}^{44}$. The rate of reactivity increases with age and reaches maximum percentages between 30 and 60 years ${ }^{57}$. The percentage of reactivity is higher in the skin test applied to rural populations, farmers, cattle raisers and other professionals working in the rural area $a^{21,27,57}$.

There are limitations to the interpretation of skin test results and to the comparison of studies. Different $P$. brasiliensis antigens lead to different rates of reactivity ${ }^{44}$. There is also evidence of cross-reactivity when the skin test is applied to people infected with Histoplasma capsulatum, although infection with both fungi should be considered ${ }^{35}$.

Many epidemiological surveys using the skin test have been performed during the second half of the $20^{\text {th }}$ century. This fact causes difficulties in determining the prevalence of paracoccidioidomycosisinfection due to the social and environmental changes that occurred later. Four surveys were conducted over the last 15 years and, except for one of them which investigated only children, the others showed rates of reactivity to the gp43 antigen of $43 \%$ to $47 \%$ among people living in the Southeast and South regions of Brazil ${ }^{39,53,57}$. Recent studies conducted in Argentina and Venezuela have also revealed $4 \%$ to $20 \%$ rates of population reactivity to $P$. brasiliensis ${ }^{20,93}$. The surveys conducted over the last decades have permitted the assumption that asymptomatic infection with $P$. brasiliensis continues to occur in rural areas and that millions of people with paracoccidioidomycosis-infection exist in South America.

Seroepidemiology: The search for anti-P. brasiliensis antibodies in population samples has also demonstrated the presence of paracoccidioidomycosis-infection. Antibodies against the exoantigen of this fungus were detected in $27 \%$ of 680 blood donors in four municipalities in Northeastern Parana, Brazil ${ }^{54}$. In an indigenous area in the North of the Minas Gerais State, 5\% and 3.9\% of the 180 inhabitants had a positive serological test to $P$. brasiliensis and $H$. capsulatum, respectively. Higher antibody titers were detected in young adults, suggesting that the infection occurs early in life ${ }^{63}$. Among those with paracoccidioidomycosis-infection, anti- $P$. brasiliensis antibody titers are barely increased and may be detected only over a short period of time. For this reason, serological tests are less sensitive than skin tests for revealing paracoccidioidomycosis-infection in population samples.

Cases of paracoccidioidomycosis-infection: Cases with a clinical diagnosis of $P$. brasiliensis infection made during the period

Table 1

Paracoccidioides brasiliensis intradermal test - paracoccidioidomycosis infection populational rate according to geographic area

\begin{tabular}{|c|c|c|c|c|c|}
\hline Country/Geographic area & $\begin{array}{c}\text { Study } \\
\mathrm{n}^{0} \text { (time) }\end{array}$ & Antigen type & $\begin{array}{l}\text { Number } \\
\text { of persons }\end{array}$ & $\begin{array}{l}\text { Reactors } \\
\% \text { (range) }\end{array}$ & References \\
\hline Brazil-North (AP-AM-RO-PA) & $8(1975-1994)$ & pol & 3,772 & $16.0(6.4-27.0)$ & $22-35$ \\
\hline Brazil-Northeast (MA-PI-CE-RN-PB-AL-BA) & $11(1974-1990)$ & pol & 4,637 & $30.6(3.0-57.4)$ & $35-73$ \\
\hline Brazil-Center West (GO-MT-MS) & $4(1968-2013)$ & pol-gp43 & 2,509 & $26.9(4.6-45.8)$ & $35-44-57-73$ \\
\hline Brazil Southeast (MG-RJ-SP) & $25(1951-2014)$ & pol-gp43 & 15,038 & $25.1(2.0-68.7)$ & $35-53-73-85$ \\
\hline Brazil-South (PR-SC-RS) & $5(1966-2005)$ & $\begin{array}{c}\text { pol-gp43 } \\
\text { MF-YF }\end{array}$ & 1,041 & $34.4(3.3-82.0)$ & $35-39-73$ \\
\hline Venezuela & $5(1971-2009)$ & pol-MF & 2,959 & $22.8(6.1-52.0)$ & $19-20-21-73$ \\
\hline Colombia & $3(1968-1993)$ & YF-MF & 5,651 & $9.7(8.9-45.0)$ & $15-73$ \\
\hline Argentina & $6(1952-1999)$ & pol-MF & 1,605 & $5.4(0.9-11.4)$ & $40-55-56-93-94$ \\
\hline Uruguay & $2(1953-1957)$ & YF & 591 & $3.2(2.0-15.4)$ & 40 \\
\hline Ecuador & $1(1986)$ & pol & 998 & 41.3 & 49 \\
\hline Chile & $1(1957)$ & YF & 137 & 0.0 & 73 \\
\hline Guyana & $1(1987)$ & pol & 49 & 31.0 & 41 \\
\hline Panama & 2 (1989) & YS & 351 & $16.5(9.0-26.2)$ & $26-27$ \\
\hline
\end{tabular}

$\%$ reactivity: geometric mean of different studies in the same region; antigen type: pol-yeast polysaccharide; gp 43 - purified glycoprotein of $43,000 \mathrm{kDa}$; MF - mycelial filtrate; YF - yeast filtrate; YS - yeast sonicated. Data of studies before 1998 were obtained from the reviews of FAVA and FAVA (reference 35), PEREIRA (reference 73), and GREER and RESTREPO (reference 40). AP - Amapa; AM - Amazonas; RO - Rondonia; PA - Para; MA - Maranhao; PI - Piaui; CE - Ceara; RN - Rio Grande do Norte; PB - Paraiba; AL - Alagoas; BA - Bahia; GO - Goias; MT - Mato Grosso; MS - Mato Grosso do Sul; MG - Minas Gerais; RJ - Rio de Janeiro; SP - São Paulo; RS - Rio Grande do Sul; PR - Parana; SC - Santa Catarina. 
when infection occurred are rare. The infection is considered to be asymptomatic or to manifest with discrete and short-lasting respiratory symptoms. Focal pulmonary lesions and hilar lymphadenomegaly have been observed in patients in whom the primary complex of $P$. brasiliensis infection was identified before the disease. The clinical and radiological expression may be different from that observed in typical cases of the disease, impairing the recognition of infection with this fungus ${ }^{62}$. On the other hand, when paracoccidioidomycosis disease affects patients with AIDS and with other types of immunosuppression, this suggests reactivation of a previously acquired subclinical infection ${ }^{66}$. Certainly, individuals who manifest paracoccidioidomycosis disease after a long time living outside Latin America are cases of subclinical disease until the onset of the mycosis. Paracoccidioidomycosis-infection has been also identified by recognizing $P$. brasiliensis in residual lesions detected at autopsy in individuals whose death was caused by other diseases ${ }^{4}$. There are also reports of rare cases of mildly symptomatic individuals with a pulmonary paracoccidioidoma, a nodular lesion caused by the persistence of the inflammatory reaction and fibrosis around the fungus acquired during the primary infection ${ }^{31}$.

\section{Paracoccidioidomycosis-disease}

Prevalence: More than 15,000 cases of paracoccidioidomycosis have been reported between 1930 and 2012, a number that only partially reflects the prevalence of the disease in Latin America. Table 2 contains data obtained from large case series and shows a high annual mean number of cases reported in the known endemic areas of the Brazilian Southeast, South, Midwest and, currently, also in the Western Amazon region of Brazil. An expressive, although smaller number of cases of the mycosis are found in the area of the States of Para, Maranhao, Piaui and Tocantins. Most of the States in the Brazilian Northeast have few autochthonous cases of the mycosis that were not included in Table 2. Colombia, Venezuela and Argentina have a smaller annual number of cases than Brazil, with the possibility of an overestimated rate for Argentina which was represented by a national study based on a survey performed in clinical laboratories ${ }^{25}$, and an underestimated rate for the other two countries. The prevalence of paracoccidioidomycosis is apparently low in other Latin American countries.

Incidence: Table 3 shows that the incidence of paracoccidioidomycosis in stabilized endemic areas of the Brazilian Southeast and South regions was estimated at 0.71 to $2.70 / 100,000$ inhabitants/year. In the microregion of Ribeirao Preto, Sao Paulo State, the annual incidence ranged from 1.5 to 3.7 new cases/100,000 inhabitants/year ${ }^{9}$. Comparatively, the mean incidence in the Rondonia State $(9.40 / 100,000$ inhabitants/year) is very high, especially in some municipalities that reached an incidence almost four times higher than the mean for the State ${ }^{96}$. These findings characterize this part of the Western Amazon region as a hyper endemic area, although already showing a tendency to a progressive reduction of incidence. South American countries have a lower incidence of paracoccidioidomycosis than Brazil. An extensive study conducted in Colombia has revealed a wide heterogeneity among the municipalities investigated, some of which had an incidence similar to those of the Brazilian Southeast ${ }^{16}$. Various studies support the estimate that the incidence of paracoccidioidomycosis in stabilized areas of Brazil ranges from one to four new cases/100,000 inhabitants/year. The incidence of the mycosis can temporarily reach higher rates in areas with great socioenvironmental changes.

Table 2

Paracoccidioidomycosis prevalence evaluated by some representative case series according to geographic area

\begin{tabular}{|c|c|c|c|c|}
\hline Country/Region/State & Cases $n^{0}$ & Period & $\begin{array}{c}\text { Annual number of } \\
\text { cases* }\end{array}$ & References \\
\hline \multicolumn{5}{|l|}{ Brazil } \\
\hline Eastern Amazonia (MA-PA-TO) & 458 & $1980-2007$ & 17.0 & $28-36$ \\
\hline Western Amazonia (RO-AM-AC) & 2,163 & $1973-2012$ & 146.1 & $88-96$ \\
\hline Center West (GO-MS-DF) & 902 & $1968-2009$ & 49.2 & $3-17-33$ \\
\hline Southeast (MG-ES-RJ-SP) & 6,784 & $1930-2012$ & 207.8 & $5-6-8-11-46-69-91$ \\
\hline South (PR-RS) & 2,169 & 1966-2009 & 140.6 & $42-50-52-80-87$ \\
\hline Mexico & 93 & $1972-2002$ & 3.1 & 51 \\
\hline Venezuela & 674 & $1984-2010$ & 25.9 & 60 \\
\hline Colombia & 940 & 1970-1999 & 32.4 & 16 \\
\hline Ecuador & 310 & $1950-1983$ & 9.4 & 49 \\
\hline Peru & 111 & 1937-1971 & 3.3 & 13 \\
\hline Argentina & 110 & 2004 & 110.0 & 25 \\
\hline Paraguay & 50 & $1960-1969$ & 5.0 & 81 \\
\hline Uruguay & 48 & $1933-1975$ & 1.1 & 23 \\
\hline
\end{tabular}

(*) The mean number of cases per year reported in different studies in the same region was summed. The studies that can duplicate data were excluded. MA - Maranhao State; PA - Para; TO - Tocantins; RO - Rondonia; AM - Amazonas; AC - Acre; GO - Goias; MS - Mato Grosso do Sul; DF - Distrito Federal; MG - Minas Gerais; ES - Espirito Santo; RJ - Rio de Janeiro; SP - São Paulo; PR - Parana; RS - Rio Grande do Sul State. 
Table 3

Incidence (new cases/100,000 inhabitants/year) of paracoccidioidomycosis according to geographic area

\begin{tabular}{lcccc}
\hline Country/City/Region & Period & $\begin{array}{c}\text { Incidence } \\
\text { (mean) }\end{array}$ & Reference \\
\hline Brazil & Sao Paulo (SP) & 1967 & 0.96 & 46 \\
& Ribeirao Preto (SP) & $1980-1999$ & 2.70 & 9 \\
& Rio de Janeiro (RJ) & 1960 & 0.71 & 40 \\
& Santa Maria (RS) & $1958-1987$ & 0.90 & 50 \\
& Rondonia (RO) & $1997-2012$ & 9.40 & 96 \\
Argentina & Chaco & 1972 & 0.80 & 40 \\
Colombia & Antioquia & 1973 & 0.35 & 40 \\
& Six municipalities* & $1970-1999$ & $0.81-3.08$ & 16 \\
Paraguay & & $1960-1969$ & 0.52 & 81 \\
\hline
\end{tabular}

(*) 6/216 municipalities with major incidence. Some data were obtained from the GREER and RESTREPO review (reference 40). SP - Sao Paulo; RJ - Rio de Janeiro; RS - Rio Grande do Sul; RO- Rondonia.

It is also possible to estimate the incidence based on the cause of deaths found in the medical records. The mortality due to paracoccidioidomycosis ranged from 0.9 to $1.0 / 1,000,000$ inhabitants/ year in Brazil, corresponding to a mean number of 168 deaths per year during the period from 1996 to $2006^{75}$. Considering $5 \%$ as the representative value for lethality of the mycosis, we may estimate its mean incidence at about 2.0/100,000 inhabitants/year, i.e., 3,360 new cases per year in Brazil ${ }^{64}$. Using the same method, the estimated incidence of the mycosis exceeds 3/1,000,000 inhabitants/year in some Brazilian States.

\section{Demography and other factors associated with the disease}

In addition to the type of immunological response in $P$. brasiliensis infection, genetic constitution, demographic characteristics and life style are factors involved in the progression to paracoccidioidomycosis.

Age: Cases ranging in age from two to 102 years have been reported ${ }^{50,74}$. The prevalence is higher between 30 and 60 years of age and less frequent during the first decade of life and after 70 years of age $\mathrm{e}^{11,91}$. The higher prevalence during adulthood is probably related to a greater exposure to the fungus during professional activities. Age is strongly associated with the clinical expression of paracoccidioidomycosis. The acute/subacute form is more prevalent during the first three decades of life and is the only form affecting children up to 15 years of age. The chronic form is the usual clinical presentation after 30 years of age ${ }^{8}$.

Gender: Children of both genders are equally affected by the mycosis ${ }^{74}$. After puberty, paracoccidioidomycosis predominates among men, but the male: female ratio varies according to geographic region, from 3:1 to 10:1 in the Brazilian Southeast and Midwest ${ }^{3,11}$, but may reach higher proportions, close to 100:1 in series of cases from the Brazilian South region and other South American countries ${ }^{40,50}$. Although infected with $P$. brasiliensis at rates similar to those for men, women are protected by the inhibitory action of beta-estradiol on the fungus, which inhibits the formation of yeast cells from the inhaled conidia and also modulates the cell immune response $\mathrm{e}^{83}$. Another reason for the lower prevalence of the mycosis among women is their less intense involvement in agricultural activities, which may also be the reason for the variability in the male: female proportion in different endemic areas. Paradoxically, adult women have a higher risk to present the more disseminated lesions of the acute/subacute form ${ }^{8}$. The reasons for this fact are unknown, but may be attributed in part to pregnancy which, in some cases, is associated with paracoccidioidomycosis ${ }^{86}$. Pregnancy temporarily reduces the immunological response and is a predisposing factor to fungal diseases.

Ethnicity: Large case series have not shown racial predisposition to the development of paracoccidioidomycosis, since patient distribution according to skin color has been similar to that of the general population. However, in a miscigenated population it was observed that blacks and mulattoes tended to have an increased prevalence of the acute/subacute form, whereas white patients showed a predominance of the chronic form of the mycosis ${ }^{8}$. This difference may be possibly related to genetic variability and the type of immunological response.

Living and working in the rural area: More than $90 \%$ of the paracoccidioidomycosis patients from the interior of Brazil had a prolonged contact with the rural area either because of their occupation, or because they lived in this environment. About $50 \%$ to $80 \%$ reported current occupation in agriculture and cattle raising, particularly direct soil management on farms dedicated to vegetable culture ${ }^{28,72}$. Coffee and tobacco cultures have been associated with paracoccidioidomycosis and apparently involve a higher risk of inhaling $P$. brasiliensis conidia present in soil ${ }^{16,85,89}$. Five to ten percent of the patients are brick layers and other civil construction workers and about $5 \%$ are professional drivers of agricultural machines or vehicles on highways ${ }^{9,59}$. Although the mycosis is strongly related to the rural environment, cases of paracoccidioidomycosis acquired in the suburban area have also been reported.

Genetic background: The different racial composition of endemic countries may eventually modulate the development and expression of paracoccidioidomycosis, e.g., the proportion of cases of the clinical forms of the disease. Some studies on the major histocompatibility complex have suggested that the genetic background may influence the development of the disease. The leukocyte antigens HLA-A9 and HLA-B13, as well as the HLA-B4 haplotype were more common among patients from Colombia and Brazil ${ }^{48,78}$, respectively, than in the corresponding general population. The $\mathrm{C}_{4} \mathrm{~B}{ }^{*}-00$ antigen of the class III major histocompatibility complex has been associated with the chronic form of paracoccidioidomycosis ${ }^{29}$.

Living conditions: Life style and certain circumstantial factors have an impact on the development of $P$. brasiliensis disease. Smoking is strongly associated with the chronic form of paracoccidioidomycosis, it is observed in more than $90 \%$ of the patients and the risk for the mycosis is 14 times higher in smokers than in nonsmokers ${ }^{32,80}$. Alcohol drinking, with a mean consumption of distilled beverages exceeding $50 \mathrm{~g}$ or $60 \mathrm{~mL}$ per day, has also been associated with the chronic form of the disease, and the cure of the patient under treatment is impaired when the mean consumption exceeds $100 \mathrm{~mL} / \mathrm{day}^{32,61}$. The role of malnutrition as a 
predisposing factor is uncertain, since in general it is a consequence of the disease itself. Nutritional changes have a greater impact on children ${ }^{74}$ and may contribute to the development of the mycosis among alcohol drinkers.

\section{Associated diseases}

Certain chronic infectious diseases and neoplasias have been associated with paracoccidioidomycosis and are diagnosed simultaneously to, before or after the mycosis. Pulmonary tuberculosis is the most common associated disease and its occurrence is also presumed to be related to smoking and to alcohol drinking, observed in many patients. This disease affects $1.7 \%$ to $15 \%$ and, exceptionally, more than $20 \%$ of the patients with paracoccidioidomycosis ${ }^{52,72,96}$. When the diseases are concomitant there may be a delay in the diagnosis of the mycosis ${ }^{76}$. Other infectious and parasite diseases such as leishmaniasis, leprosy, Chagas disease and strongyloidiasis affect a small portion of patients and are probably a consequence of common predisposing conditions?.

Neoplasias occur in $0.16 \%$ to $14.1 \%$ of patients with paracoccidioidomycosis and in some of these cases the diagnosis of the two medical conditions is made simultaneously, as reported in a review by SHIKANAIYASUDA et $_{\text {al. }}{ }^{84}$. There is a predominance of carcinomas commonly located in the respiratory and digestive tracts, but the mycosis has also been observed in association with lymphomas and leukemia. Carcinomas are more frequent among patients with the chronic form of paracoccidioidomycosis and in many cases they are located in the same anatomical site of the fungal lesion or close to it. In addition to the fact that the patients have risk factors for the development of both the mycosis and of the neoplasia, an increased risk for neoplasia is presumed to exist due to a modified immunological response and/or the chronic inflammation caused by the persistence of $P$. brasiliensis in the tissues ${ }^{80}$. However, there is no scientific evidence showing that paracoccidioidomycosis is an independent risk factor for the development of neoplasias.

Opportunistic paracoccidioidomycosis: P. brasiliensis may be an occasional opportunistic agent in patients with impaired cellular immune response, usually as a consequence of reactivation of the fungus in residual lesions of a previous infection. Several cases of paracoccidioidomycosis affecting patients with hematological or solid organ neoplasias have been reported, and the mycosis was diagnosed simultaneously to or after the occurrence of cancer in $40 \%$ to $60 \%$ of them ${ }^{80,84}$. Opportunistic paracoccidioidomycosis has also been reported in patients submitted to renal transplantation ${ }^{98}$, in isolated cases of CD40L (Ligand) deficiency ${ }^{14}$ and in patients with genetic polymorphisms in the interleukin 12 receptor ${ }^{65}$.

P. brasiliensis/HIV coinfection has been reported in South American countries, and in Brazil in particular. In endemic areas, $1.4 \%$ to $1.5 \%$ of AIDS patients present opportunistic paracoccidioidomycosis, usually more disseminated, with a higher early mortality rate and lower percentage of cure after antifungal treatment ${ }^{66,71}$. HIV infection was detected in approximately $5 \%$ of the patients with the mycosis ${ }^{66}$, and $1.4 \%$ of the deaths caused by fungal disease in AIDS patients of Brazil have been attributed to paracoccidioidomycosis ${ }^{75}$. The epidemiological characteristics of the mycosis in patients with AIDS differ from those known for the endemic paracoccidioidomycosis, since the patients are more urbanized and are younger, with a greater proportion of women.

\section{Lethality and mortality}

Lethality: Before the introduction of sulfonamides in 1940, all patients with paracoccidioidomycosis died due to complications of progressive disease. Even with the introduction of antifungal agents, lethality continued to be high, about $16.2 \%$ to $27.0 \%$ at the end of treatment, according to a review of the data obtained in some Brazilian studies $^{30}$. Death was the outcome for $12.3 \%$ of cases in a series of patients with the chronic form of the mycosis ${ }^{5}$. In Argentina, evaluation at the end of treatment showed the occurrence of death in $2.2 \%$ of 90 patients ${ }^{68}$. Two more recent series involving a large number of cases showed $7.6 \%$ and $6.1 \%$ lethality in different endemic areas of Brazil ${ }^{72,96}$. A lethality rate of $9.3 \%$ was observed among children attending a university hospital in the Southeast of Brazil ${ }^{74}$. The deaths occurring before or during the early phase of treatment are related to delayed diagnosis, multiple lesions due to dissemination of $P$ brasiliensis and complications of paracoccidioidomycosis, such as respiratory failure, adrenal insufficiency, tissue necrosis causing perforation of the viscera and hemorrhage, lymphocyte depletion, and advanced age ${ }^{10}$. The deaths occurring over the years following treatment of the mycosis are usually a consequence of sequelae, particularly respiratory dysfunction.

Mortality: In Brazil, 3,181 deaths due to paracoccidioidomycosis have been recorded from 1980 to 1985 , corresponding to a mean annual mortality rate of 1.45 per million inhabitants ${ }^{24}$. Of the deaths due to fungal infections, $51 \%$ were attributed to paracoccidioidomycosis ${ }^{75}$. Deaths occurred in all Brazilian States, although mortality rates were higher in endemic areas in the South, Midwest and Western Amazon regions. The distributions according to sex, age and professional activity were similar to those of paracoccidioidomycosis-disease. The deaths mainly occurred during the winter months, apparently as a consequence of complications and sequelae in the respiratory tract ${ }^{82}$. In Brazil, between 1996 and 2006, paracoccidioidomycosis was recorded as an associated cause of death in 0.67 per 1,000 deaths of patients with $\operatorname{AIDS}^{75}$.

\section{Paracoccidioidomycosis in animals}

The disease and particularly $P$. brasiliensis infection have been demonstrated in different species of domestic and wild animals. An armadillo species (Dasypus novemcinctus) is more associated with the eco-epidemiology of paracoccidioidomycosis, being frequently infected or showing histopathological changes suggestive of disease caused by $P$. brasiliensis. In addition to having a geographic distribution approximately equal to that of the mycosis, armadillos dig and produce aerosols with soil particles and are probably infected by inhaling fungal conidia in suspension in the air, as is the case in humans ${ }^{77}$. Disseminated paracoccidioidomycosis was also detected in a two-toed sloth that died after being captured in Guyana, a fact that demonstrates the endemicity of this region ${ }^{90}$. Structures similar to those of $P$. brasiliensis were observed in the liver of a squirrel monkey captured in Bolivia ${ }^{43}$. Regarding domestic animals, paracoccidioidomycosis was confirmed by isolation of the fungus and/or histopathological examination in two dogs from the Brazilian Southeast which showed lymphadenomegaly ${ }^{34,79}$.

Serological surveys or skin tests with $P$. brasiliensis antigens have revealed the existence of paracoccidioidomycosis-infection in cats, dogs, chickens, pigs, cattle, horses, sheep, goats, rabbits and in monkeys and in other free or captive wild animals. Anti-P. brasiliensis antibodies 
have been detected in $2 \%$ to $90 \%$ of wild or urban animals evaluated and the percentage of infected urban animals was related to the degree of exposure to the environment. Dogs living in the rural area have a higher rate of infection than dogs living in the urban $\operatorname{area}^{37}$. Freely raised rabbits have higher rates of infection than caged animals and $83 \%$ of the rabbits exposed to natural infection develop antibodies against $P$. brasiliensis $^{7}$. However, no lesions caused by P. brasiliensis have been detected in anatomopathological exams of animals reactive to antigens of the fungus in serological or skin tests ${ }^{37}$. This suggests that, except for armadillos, there is low risk of paracoccidioidomycosis-infection to progress to fungal dissemination and disease in animals.

\section{CONCLUSION}

The epidemiology of paracoccidioidomycosis had already been delineated since the middle of the $20^{\text {th }}$ century ${ }^{40}$ but new data have shown that it is not stable and may undergo changes along time. More than a simple contact with the rural area and the forest, the type of human interaction with the environment has a great impact on the acquisition of infection with $P$. brasiliensis. This involves deforestation, extensive and continued agriculture and human migration to scarcely inhabited and unexplored regions, in addition to the environmental impact of large constructions. New endemic regions have been revealed in Brazil since the second half of the $20^{\text {th }}$ century. The urbanization of the population under inappropriate conditions has favored infection and disease at the periphery of cities. On the other hand, the prevalence of the acute/ subacute form of the mycosis tends to be reduced in the Midwest region and a similar tendency was observed for the paracoccidioidomycosis mortality in Brazil. The clinical expression of paracoccidioidomycosis is associated with individual demographic characteristics and perhaps with the racial composition of the population of each endemic area. Paracoccidioidomycosis has morbidity and mortality rates comparable to those of other chronic endemic parasite infections and is considered to be an occupational disease and, due to frequent sequelae, its medical-social impact may extend for years after antifungal treatment.

\section{RESUMO}

\section{Epidemiologia da paracoccidioidomicose}

As características epidemiológicas da paracoccidioidomicose foram revistas e atualizadas. Novas áreas endêmicas brasileiras foram discutidas na seção de distribuição geográfica da micose. A infecção subclínica por Paracoccidioides brasiliensis foi discutida com base em pesquisas realizadas com testes cutâneos com antígenos do fungo, estudos soroepidemiológicos e em casos de doença, fora da América Latina. Grandes séries de casos permitiram a comparação da prevalência da micose em diferentes regiões, sua incidência estimada e fatores de risco para o desenvolvimento da doença. Aspectos modulando a expressão de formas subclínicas da paracoccidioidomicose foram igualmente apresentados. Esta revisão também trata de doenças associadas à micose, paracoccidioidomicose oportunista, letalidade, mortalidade e infecção e doença em animais.

\section{REFERENCES}

1. Ajello L, Polonelli L. Imported paracoccidioidomycosis: a public health problem in non-endemic areas. Eur J Epidemiol. 1985;1:160-5.
2. Almeida FP, Lacaz CS, Cunha AC. Dados estatísticos sobre a granulomatose paracoccidióidica (Blastomycosis sul-americana ou paracoccidioidose). Rev Bras Med. 1946;3:91-2.

3. Andrade ALSS. Paracoccidioidomicose linfático abdominal. Contribuição ao seu estado. Rev Patol Trop. 1983;12:165-256.

4. Angulo-Ortega A. Calcifications in paracoccidioidomycosis: are they the morphological manifestation of subclinical infections? In: Pan American Symposium on Paracoccidioidomycosis, I, Medelin, 1971. Proceedings. Washington: PAHO; 1972. Scient Publ. no 254. p. 129-33.

5. Azevedo JF, Lisboa C di SG. Paracoccidioidomicose: estudo de 106 casos. J Pneumol 1980;6:30-3.

6. Barrozo LV, Mendes RP, Marques SA, Bernard G, Siqueira Silva ME, Bagagli E. Climate and acute/subacute paracoccidioidomycosis in a hyper-endemic area in Brazil. Int J Epidemiol. 2009;38:1642-9.

7. Belitardo DR, Calefi AS, Sbeghen MR, de Oliveira GG, Watanabe MA, de Camargo $\mathrm{ZP}$, et al. Paracoccidioides brasiliensis infection in domestic rabbits (Oryctolagus cuniculus) . Mycoses. 2014;57:222-7.

8. Bellissimo-Rodrigues F, Bollela VR, da Fonseca BAL, Martinez R. Endemic paracoccidioidomycosis: relationship between clinical presentation and patients' demographic features. Med Mycol. 2013;51:313-8.

9. Bellissimo-Rodrigues F, Machado AA, Martinez R. Paracoccidioidomycosis epidemiological features of a 1,000-cases series from a hyperendemic area on the Southeast of Brazil. Am J Trop Med Hyg. 2011;85:546-50.

10. Benard G, Patzina RL, Schwab JB, Gabriel TC, Ho YL. Fatal septic shock due to a disseminated chronic form of paracoccidioidomycosis in an aged woman. Med Mycol. 2012;50:407-11.

11. Blotta MH, Mamoni RL, Oliveira SJ, Nouér SA, Papaiordanou PM, Goveia A, et al. Endemic regions of paracoccidioidomycosis in Brazil: a clinical and epidemiologic study of 584 cases in the southeast region. Am J Trop Med Hyg. 1999;61:390-4.

12. Buitrago MJ, Cuenca-Estrella M, [Current epidemiology and laboratory diagnosis of endemic mycosis in Spain]. Enferm Infecc Microbiol Clin. 2012;30:407-13.

13. Burstein Z. Aspectos clínicos de la Blastomicosis sudamericana (Paracoccidioidomicosis) en el Perú. Rev Peru Exp Salud Publica. 2002;19:43-7.

14. Cabral-Marques O, Schimke L F, Pereira PV, Falcai A, de Oliveira JB, Hackett M, et al. Expanding the clinical and genetic spectrum of human CD40L deficiency: the occurence of paracoccidioidomycosis and other unusual infections in Brazilian patients. J Clin Immunol. 2012;32:212-20.

15. Cadavid D, Restrepo A. Factors associated with Paracoccidioides brasiliensis infection among permanent residents of three endemic areas in Colombia. Epidemiol Infect. 1993; 111:121-33.

16. Calle D, Rosero DS, Orozco LC, Camargo D, Castañeda E, Restrepo A. Paracoccidioidomycosis in Colombia: an ecological study. Epidemiol Infect. 2001;126:309-15.

17. Campos MV, Penna GO, Castro CN, Moraes MA, Ferreira MS, Santos JB Paracoccidioidomicose no hospital universitário de Brasília. Rev Soc Bras Med Trop. 2008;41:169-72.

18. Castro RM, Cuce LC, Fava Netto C. Paracoccidioidomicose. Inoculação acidental 'anima nobile": relato de um caso. Med Cutan Ibero Lat Am. 1975;4:289-92.

19. Cermeño J, Cermeño J, Godoy G, Hernández I, Orellán Y, Blanco Y, et al. Epidemiological study of paracoccidioidomycosis and histoplasmosis in a suburb of San Félix City, Bolivar State, Venezuela. Invest Clin. 2009;50:213-20. 
20. Cermeño JR, Cermeño JJ, Hernandéz I, Godoy G, Cermeño JJ, Cabello I, et al. Histoplasmine and paracoccidine epidemiological study in Upata, Bolivar State, Venezuela. Trop Med Int Health. 2005;10:216-9.

21. Cermeño JR, Hernández I, Cermeño JJ, Godoy G, Cermeño JJ, Orellán Y, et al. Epidemiological survey of histoplasmine and paracoccidioidine skin reactivity in an agricultural area in Bolivar State, Venezuela. Eur J Epidemiol. 2004;19:189-93.

22. Coimbra Junior CE, Wanke B, Santos RV, do Valle AC, Costa RL, Zancopé-Oliveira RM. Paracoccidioidin and histoplasmin sensitivy in Tupi-Mondé Amerindian populations from Brazilian Amazonia. Ann Trop Med Parasitol. 1994;88:197-207.

23. Conti Díaz IA, Calegari LF. Paracoccidioidomicosis en Uruguay: su estado y problemática actuales. Bol Of Sanit Panam. 1979;86:219-29.

24. Coutinho ZF, da Silva D, Lazéra M, Petri V, Oliveira RM, Sabroza PC, et al. Paracoccidioidomycosis mortality in Brazil (1980-1995). Cad Saude Publica. 2002; 18:1441-54

25. Davel G, Canteros CE. Situación de las micosis en la República Argentina. Rev Argent Microbiol. 2007;39:28-33.

26. de Martin MC, de Lopéz C. [Infection caused by Paracoccidioides brasiliensis infection in Panamanian children. Preliminary report]. Rev Med Panama. 1989;14:135-8.

27. de Martin MC, Suaréz M. [Infection caused by Paracoccidioides brasiliensis in people living in Cocle and Veraguas, Republic of Panama]. Rev Med Panama. 1989;14:112-5.

28. de Matos WB, dos Santos GMC, da Silva UEB, Gonçalves E da G do R, da Silva, AR. Paracoccidioidomycosis in the state of Maranhão, Brazil: geographical and clinical aspects. Rev Soc Bras Med Trop. 2012;45:385-9.

29. de Messias IJ, Reis A, Brenden M, Queiroz-Telles F, Mauff G. Association of major histocompatibility complex class III complement components $\mathrm{C} 2, \mathrm{BF}$, and $\mathrm{C} 4 \mathrm{~J}$ with Brazilian paracoccidioidomycosis. Complement Inflamm. 1991;8:288-93.

30. Del Negro G. Tratamento da paracoccidioidomicose. Rev Assoc Med Bras. 1974;20:231-4.

31. dos Santos JW, Michel GT, Londero AT. Paracoccidioidoma: case report and review. Mycopathologia. 1997;137:83-5.

32. dos Santos WA, da Silva BM, Passos ED, Zandonade E, Falqueto A. Associação entre tabagismo e paracoccidioidomicose: um estudo de caso-controle no estado do Espirito Santo, Brasil. Cad Saude Publica. 2003;19:245-53

33. Fabris LR, Andrade UV, Ferreira dos Santos A, Marques AP, Oliveira SM, Mendes RP, et al. Decreasing prevalence of the acute/subacute clinical form of paracoccidioidomycosis in Mato Grosso do Sul State, Brazil. Rev Inst Med Trop Sao Paulo. 2014;56:121-5.

34. Farias MR, Condas LAZ, Ribeiro MG, Bosco S de M, Muro MD, Werner J, et al. Paracoccidioidomycosis in a dog: case report of generalized lymphadenomegaly. Mycopathologia. 2011;172:147-52.

35. Fava S di C, Fava Netto C. Epidemiologic surveys of histoplasmin and paracoccidioidin sensitivity in Brazil. Rev Inst Med Trop Sao Paulo. 1998;40:155-64.

36. Fonseca ER, Pardal PP, Severo LC. Paracoccidioidomicose em crianças em Belém do Pará. Rev Soc Bras Med Trop. 1999;32:31-3.

37. Fontana FF, dos Santos CT, Esteves FM, Rocha A, Fernandes GF, do Amaral CC et al. Seroepidemiological survey of paracoccidioidomycosis infection among urban and rural dogs from Uberaba, Minas Gerais, Brazil. Mycopathologia. 2010;169:159-65.

38. Forjaz MHH, Fishman O, de Camargo ZP, Vieira Filho JPB, Colombo AL. Paracoccidioidomicose em índios brasileiros da tribo Suruí: estudo clínico-laboratorial de 2 casos. Rev Soc Bras Med Trop. 1999;32:571-5.
39. Fornajeiro N, Maluf ML, Takahachi G, Svidzinski TI. Inquérito epidemiológico sobre a paracoccidioidomicose utilizando a gp43 em dois municípios do nordeste do Paraná, Brasil. Rev Soc Bras Med Trop. 2005;38:191-3.

40. Greer DL, Restrepo AM. La epidemiologia de la paracoccidioidomicosis. Bol Of Sanit Panam. 1977;82:428-45.

41. Hay RJ, Rose P, Jones TR. Paracoccidioidin sensitization in Guyana: a preliminary skin test survey in hospitalized patients and laboratory workers. Trans R Soc Trop Med Hyg. 1987;81:46-8.

42. Hildebrand TM, Rosario Filho NA, Telles Filho FQ, Costa O, Miasaki N, Mira JGS, et al. Paracoccidioidomicose na criança: aspectos clínicos e laboratoriais em 25 casos. J Pediatr (Rio J). 1987;63:92-7.

43. Johnson WD, Lang CM. Paracoccidioidomycosis (South American Blastomycosis) in a squirrel monkey (Saimiri sciureus). Vet Pathol. 1977;14:368-71.

44. Kalmar EM, Alencar FE, Alves FP, Pang LW, Del Negro GM, Camargo ZP, et al Paracoccidioidomycosis: an epidemiologic survey in a pediatric population from the Brazilian Amazon using skin tests. Am J Trop Med Hyg. 2004;71:82-6.

45. Kamei K, Sano A, Kikuchi K Makimura K, Niimi M, Suzuki K, et al. The trends of imported mycoses in Japan. J Infect Chemother. 2003;9:16-20.

46. Lacaz C da S. Micologia médica. $5^{\text {th }}$ ed. São Paulo: Sarvier; 1967.

47. Laccourreye O, Mirghani H, Brasnu D, Badoual C. Imported acute and isolated glottic paracoccidioidomycosis. Ann Otol Rhinol Laryngol. 2010;119:88-92.

48. Lacerda GB, Arce-Gomez B, Telles Filho FQ. Increased frequency of HLA- B40 in patients with paracoccidioidomycosis. J Med Vet Mycol. 1988;26:253-6.

49. Lazo RF, Fernández T, Mera R. Prevalencia de la paracoccidioidomicosis e histoplasmosis en la cuenca del Rio Guayas. Rev Ecuat Hyg Med Trop. 1987;37:15-35.

50. Londero AT, Ramos CD. Paracoccidioidomicose. Estudo clínico e micológico de 260 casos observados no interior do Estado do Rio Grande do Sul. J Pneumol. 1990;16:129-32.

51. López-Martinez R, Hernandéz-Hernandéz F, Mendez-Toiar LJ, Manzano-Gayosso P, Bonifaz A, Arenas R, et al. Paracoccidioidomycosis in Mexico: clinical and epidemiological data from 93 new cases (1972-2012). Mycoses. 2014;57:525-30.

52. Loth EA, Castro SV, Silva JR, Gandra RF. Ocurrence of 102 cases of paracoccidioidomycosis in 18 months in the Itaipu Lake region, Western Paraná. Rev Soc Bras Med Trop. 2011;44:636-7.

53. Magalhães EM, Ribeiro C de F, Dâmaso CS, Coelho LF, Silva RR, Ferreira FB, et al Prevalence of paracoccidioidomycosis infection by intradermal reaction in rural areas in Alfenas, Minas Gerais, Brazil. Rev Inst Med Trop Sao Paulo. 2014;56:281-5.

54. Maluf ML, Pereira SR, Takahachi G, Svidzinski TI. Prevalência de paracoccidioidomicoseinfecção determinada através de teste sorológico em doares de sangue na região nordeste do Paraná, Brasil. Rev Soc Bras Med Trop. 2003;36:11-6.

55. Mangiaterra M, Alonso J, Galvan M, Giusano G, Gorodner J. Histoplasmin and paracoccidioidin skin reactivity in infantile population of northern Argentina. Rev Inst Med Trop Sao Paulo. 1996;38:349-53.

56. Mangiaterra ML, Giusiano GE, Alonso JM, Gorodner JO. Infection par Paracoccidioides brasiliensis dans une région subtropicale avec changements importants de l'environnement. Bull Soc Pathol Exot. 1999;92:173-6.

57. Marques AP, Oliveira SM, Rezende GR, Melo DA, Fernandes-Fitts SM, Pontes ER, et al. Evaluation of Paracoccidioides brasiliensis infection by the gp43 intradermal test in rural settlements in Central-West Brazil. Mycopathology. 2013;176:41-7. 
58. Marques da Silva SH, Rodrigues AM, de Hoog S, Silveira-Gomes F, Camargo ZP. Occurence of Paracoccidioides lutzii in the Amazon region: description of two cases. Am J Trop Med Hyg. 2012;87:710-4.

59. Marques SA, Franco MF, Mendes RP, Silva NC, Bacilli C, Curcelli ED, et al. Aspectos epidemiológicos da paracoccidioidomicose na área endêmica de Botucatu (São Paulo-Brasil). Rev Inst Med Trop Sao Paulo. 1983;25:87-92.

60. Martínez Mendéz D, Hernándes Valles R, Alvarado P, Mendonza M. Las micosis en Venezuela: casuística de los grupos de trabajo en micología (1984-2010). Rev Iberoam Micol. 2013;30:39-46.

61. Martinez R, Moya MJ. Associação entre paracoccidioidomicose e alcoolismo. Rev Saude Publica. 1992;26:12-6.

62. Martinez R, Moya MJ. Complexo primário da paracoccidioidomicose e hipereosinofilia. J Bras Pneumol. 2009;35:1259-62.

63. Martinez R, Vitali LH, Henriques JH, Machado AA, Albernaz A, Lima AA. Inquérito soroepidemiológico para infecções por fungos causadores de micoses sistêmicas na Reserva Indígena Xacriabá, Estado de Minas Gerais. Rev Soc Bras Med Trop. 2002;35:347-50

64. Martinez R. Paracoccidioidomycosis: the dimension of the problem of a neglected disease. Rev Soc Bras Med Trop. 2010;43:480.

65. Moraes Vasconcelos D, Grumach AS, Yamaguti A, Andrade ME, Fieschi C, de Beaucoudrey L, et al. Paracoccidioides brasiliensis disseminated disease in a patient with inherited deficiency in the beta1 subunit of the interleukin (IL)-12/IL23 receptor. Clin Infect Dis. 2005;41:e31-7.

66. Morejón KM, Machado AA, Martinez R. Paracoccidioidomycosis in patients infected with and not infected with human immunodeficiency virus: a case control study. Am J Trop Med Hyg. 2009;80:359-66.

67. Navascués A, Rubio MT, Monzón FJ. Paracoccidioidomicosis en inmigrante ecuatoriano. Enferm Infecc Microbiol Clin. 2013;31:415-6.

68. Negroni R, Robles AM, Arechavala A, Tuculet AM, Galimbert R. Ketoconazole in the treatment of paracoccidioidomycosis and histoplasmosis. Rev Infect Dis. 1980;2:6439.

69. Neves FF, Gerolin GP, Tavares MG, Castro-Silva MH, Lopes GP, Michelin MA, et al. Epidemiological and clinical profile of 137 patients with paracoccidioidomycosis in Uberaba, Minas Gerais, Brazil. Biomédica. 2008;28(suppl. 1):144.

70. Onda H, Komine M, Murata S, Ohtsuki M. Letter: imported paracoccidioidomycosis in Japan. Dermatol Online J. 2011;17:11.

71. Paniago AM, de Freitas AC, Aguiar ES, Aguiar JI, da Cunha RV, Castro AR, et al. Paracoccidioidomycosis in patients with human immunodeficiency virus: review of 12 cases observed in an endemic region on Brazil. J Infect. 2005;51:248-52.

72. Paniago AMM, Aguiar JIA, Aguiar ES, da Cunha RV, Pereira GR, Londero AT, et al. Paracoccidioidomicose: estudo clínico e epidemiológico de 422 casos observados no Estado do Mato Grosso do Sul. Rev Soc Bras Med Trop. 2003;36:455-9.

73. Pereira AJCS. Inquérito intradérmico para paracoccidioidomicose em Goiânia. Rev Patol Trop. 1988;17:157-86.

74. Pereira RM, Bucaretchi F, Barison E de M, Hessel G, Tresoldi AT. Paracoccidioidomycosis in children: clinical presentation, follow-up and outcome. Rev Inst Med Trop Sao Paulo. 2004;46:127-31

75. Prado M, Silva MB, Laurenti R, Travassos LR, Taborda CP. Mortality due to systemic mycoses as a primary cause of death or in association with AIDS in Brazil: review from 1996 to 2006. Mem Inst Oswaldo Cruz. 2009;104:513-21.
76. Quagliato Júnior R, Grangeia T de AG, Massucio RA de C, de Capitani EM, Rezende S de M, Balthazar AB. Association between paracoccidioidomycosis and tuberculosis: reality and misdiagnosis. J Bras Pneumol. 2007;33:295-300.

77. Restrepo A, McEwen JG, Castañeda E. The habitat of Paracoccidioides brasiliensis: how far from solving the riddle? Med Mycol. 2001;39:233-41.

78. Restrepo FM, Restrepo M, Restrepo A. Blood groups and HLA antigens in paracoccidioidomycosis. Sabouraudia. 1983;21:35-9.

79. Ricci G, Motta FT, Wakamatsu A, Serafim RC, Borra RC, Franco M. Canine paracoccidioidomycosis. Med Mycol. 2004;42:379-83.

80. Rodrigues G de S, Severo CB, Oliveira F de M, Moreira J da S, Prolla JC, Severo LC. Association between paracoccidioidomycosis and cancer. J Bras Pneumol 2010;36:356-62

81. Rolón PA. Paracoccidioidomicosis: epidemiologia en la Republica del Paraguay, centro Sud América. Mycopathologia. 1976;59:67-80.

82. Santo AH. Tendência da mortalidade relacionada à paracoccidioidomicose, Estado de São Paulo, Brasil, 1985 a 2005: estudo usando causas múltiplas de morte. Rev Panam Salud Publica. 2008;23:313-24

83. Shankar J, Restrepo A, Clemons KV, Stevens DA. Hormones and the resistance of women to paracoccidioidomycosis. Clin. Microbiol Rev. 2011;24:296-313.

84. Shikanai-Yasuda MA, Conceição YM, Kono A, Rivitti E, Campos AF, Campos SV Neoplasia and paracoccidioidomycosis. Mycopathologia. 2008;165:303-12.

85. Silva-Vergara ML, Martinez R. Inquérito epidemiológico com paracoccidioidina e histoplasmina em área agrícola de café em Ibiá, Minas Gerais, Brasil. Rev Iberoam Micol. 1998;15:294-7.

86. Slevogt H, Tintelnot K, Seybold J, Suttorp N. Lymphadenopathy in a pregnant woman from Brazil. Lancet. 2004;363:1282

87. Souza SP de, Jorge VM, Xavier MO. Paracoccidioidomycosis in southern Rio Grande do Sul: a retrospective study of histopathologically diagnosed cases. Braz J Microbiol 2014;45:243-7

88. Talhari S, Cunha MG, Sehettini AP, Talhari AC. Deep mycoses in Amazon region. Int J Dermatol. 1988;27:481-4

89. Torrado E, Castañeda E, de la Hoz F, Restrepo A. Paracoccidioidomicosis: definición de las áreas endémicas de Colombia. Biomedica. 2000;20:327-34

90. Trejo-Cháves A, Ramiréz-Romero R, Ancer-Rodríguez J, Nevárez-Garza AM, RodriguézTrovar LE. Disseminated paracoccidioidomycosis in a Southern two-toed sloth (Choloepus didactylus). J Comp Pathol. 2011;144:231-4.

91. Valle ACF, Wanke B, Fernandes NC, Peixoto TC, Perez M. Tratamento da paracoccidioidomicose: estudo retrospectivo de 500 casos. I. Análise clínica, laboratorial e epidemiológica. An Bras Dermatol. 1992;67:251-4.

92. Van Damme PA, Bierenbroodspot F, Telgt DS, Kwakman JM, De Wilde PC, Meis JF. A case of imported paracoccidioidomycosis: an awkward infection in The Netherlands. Med Mycol. 2006;44:13-8.

93. Van Gelderen de Komaid A, Durán E, Borges de Kestelman I. Histoplasmosis and paracoccidioidomycosis in Northwestern Argentina. III. Epidemiological survey in Vipos, La Toma and Choromoro-Trancas, Tucumán, Argentina. Eur J Epidemiol. $1999 ; 15: 383-8$

94. Van Gelderen de Komaid A, Durán EL. Histoplasmosis in northwestern Argentina. II. Prevalence of histoplasmosis capsulati and paracoccidioidomycosis in the population of Chusca, Gonzalo and Potero in the province of Tucumán. Mycopathologia $1995 ; 129: 17-23$ 
95. Vargas FJ. Paracoccidioidomycosis in Bolivia. Biomedica. 2008;28(suppl 1):142.

96. Vieira G de D, Alves T de C, Lima SM, Camargo LM, Souza CM. Paracoccidioidomycosis in a western Brazilian Amazon State: clinical-epidemiologic profile and spatial distribution of the disease. Rev Soc Bras Med Trop. 2014;47:63-8.
97. Walker SL, Pembroke AC, Lucas SB, Vega-Lopez F. Paracoccidioidomycosis presenting in UK. Br J Dermatol. 2008;158:624-6.

98. Zavascki AP, Bienardt JC, Severo LC. Paracoccidioidomycosis in organ transplant recipient: case report. Rev Inst Med Trop Sao Paulo. 2004;46:279-81. 